\title{
3.5 Людський капітал України у глобальному вимірі
}

Економіка України має значний запас національного багатства, серед складових якого чільне місце займає людський капітал, який став ключовою цінністю суспільства у XXI столітті та основоположним фактором економічного зростання. Проте, внаслідок поширення COVID-19 людський капітал знаходиться у кризовому становищі. У першу чергу, пандемія коронавірусної інфекції позначилася на здоров’ї людей, що привело до тривалих порушень або ускладнень у здоров’і, загостренні хронічних захворювань тощо. Проте, найбільшою й необерненою стала втрата значної кількості людей. Так, станом на 5 грудня 2020 року в Україні маємо 88280 летальних випадків [214]. Серед інших негативних проявів слід визнати вплив на освіту, що передбачає тимчасове закриття шкіл (карантинні заходи) або перехід на дистанційне навчання. Крім того, пандемія суттєво позначилася на зменшені грошових доходів населення. Тому не дивною стає точка зору, що криза привела до найбільшого скорочення економічної активності з часів Великої Депресії [215]. В таких умовах варто очікувати загострення проблеми розвитку людського капіталу, для відновлення якого недостатньо лише державної підтримки, оскільки суттєвою проблемою стане пошук додаткових значних інвестиційних ресурсів, необхідних для відновлення системи охорони здоров’я та освітньо-наукового потенціалу. Отже, пандемія COVID-19 стала загрозою розвитку людського капіталу, що також яскраво відображається у глобальному вимірі.

Проведений контент-аналіз сучасних публікацій, які відображають науково-теоретичні аспекти людського капіталу, дає можливість виділити три основні підходи до розуміння сутності поняття «людський капітал».

За першим підходом людський капітал ототожнюють 3 робочою силою чи виробничими здібностями людини. Яскравою ілюстрацією такого бачення $\epsilon$ визначення, запропоноване О.А. Грішновою: «Людський капітал - це сформований i розвинений у результаті інвестицій i накопичений людиною певний запас здоров’я, знань, навичок, здібностей, мотивацій, який 
цілеспрямовано використовується в тій чи іншій сфері економічної діяльності, сприяє зростанню продуктивності праці і завдяки цьому впливає на зростання доходів свого власника, прибутку підприємства та національного доходу» [216, С. 247-248]. Слід зазначити, що такий підхід дещо розширює складові людського капіталу, виділені С. Фішером, для якого «людський капітал це лише міра втіленої в людину здатності приносити дохід, що включає вроджений хист, талант, а також набуту освіту та кваліфікацію» [217, С. 516]. Таким чином, трактування вітчизняної дослідниці є більш цілісним, оскільки визначає джерела формування здібностей людини (накопичення та інвестиції).

Підсумовуючи, можна твердити, що за таким підходом трактування «людського капіталу» як економічної категорії акцентується на трьох аспектах: 3’ясування джерел формування та примноження людського капіталу; розкриття внутрішньої структури людського капіталу; визначення можливостей (напрямів) використання людського капіталу в національній економіці.

Другий підхід характеризується історико-логічною спрямованістю й передбачає визначення людського капіталу як особливої форми життєдіяльності і суспільних відносин, що склалися в постіндустріальну стадію розвитку. Представники такого напряму особливу увагу приділяють умовам, за яких робоча сила перетворюється у людський капітал, до яких відносять гуманізацію суспільних відносин, соціалізацію, господарський розвиток. Наприклад, М.М. Критський вважає, що «людський капітал є загальною конкретною формою людської життєдіяльності і підсумком історичного руху суспільства» [218, С. 230].

В межах третього підходу людський капітал ототожнюється 3 поняттям людський потенціал. Формування такого розуміння стало наслідком прийняття Концепції розвитку людського капіталу ПРООН. За такою концепцією, під розвитком людського потенціалу розуміється «процес безперервного збалансованого розширення людських можливостей. Економічні та соціальні передумови реалізації потенціалу людини можуть бути дуже різними i змінюватися протягом його життя. Але основними константами визнаються три 
складові, а саме довголіття і здоров'я; освітнє і професійне зростання; гідний рівень добробуту» [219, с. 159-160].

Отже, аналіз існуючих підходів до визначення сутності поняття «людський капітал» дає підстави зробити висновок, що людський капітал - це капітал людини у вигляді фізико-психологічних та інтелектуальних якостей, а також здібностей, вмінь, навичок, знань, мотивації, що генеруються та акумулюються протягом значного терміну часу й потребують постійних інвестицій, які у подальшому будуть мати позитивний соціально-економічний ефект.

Людський капітал як економічна категорія має певні властивості, що дозволяє визнати його як основний компонент економічного зростання країни, а саме: 1) без задіяння людського капіталу є неможливими інновації, а відтак і розвиток інноваційної діяльності як запоруки добробуту країни та їі визнання на міжнародній арені. Саме тому в сучасному світі людський капітал є більш цінним ресурсом ніж природний капітал; 2) людський капітал має тенденцію до нагромадження, адже його складовими є знання, досвід, навички, що виступають у вигляді певного запасу, який постійно збільшується; 3) формування людського капталу вимагає як від людини, так і від суспільства в цілому значних витрат (фінансові, часові, соціальна підтримка, психологічні зусилля тощо), раціональність яких прямопропорційно позначається на стійкому економічному розвитку та інноваційному зростанні; 4) інвестиції в людський капітал $\epsilon$ найбільш вигідними у порівнянні з іншими об’єктами, оскільки економічний та соціальний ефект від таких вкладень є довготривалим та має інтегральний характер; 5) людський капітал (в не залежності від джерел його формування: державні, приватні, сімейні) може використовувати та контролювати лише людина, що виступає його носієм.

Сьогодні існує значна кількість міжнародних рейтингів, що прямо або опосередковано відображають стан розвитку людського капіталу. Основним показником рівня суспільного розвитку та якості життя населення є індекс людського розвитку (Human Development Index), що визначається як сукупність показників рівня розвитку людини у конкретній країні. ІЛР відображає 
досягнення країни за такими напрямами як стан здоров’я, отримання освіти та фактичного доходу населення.

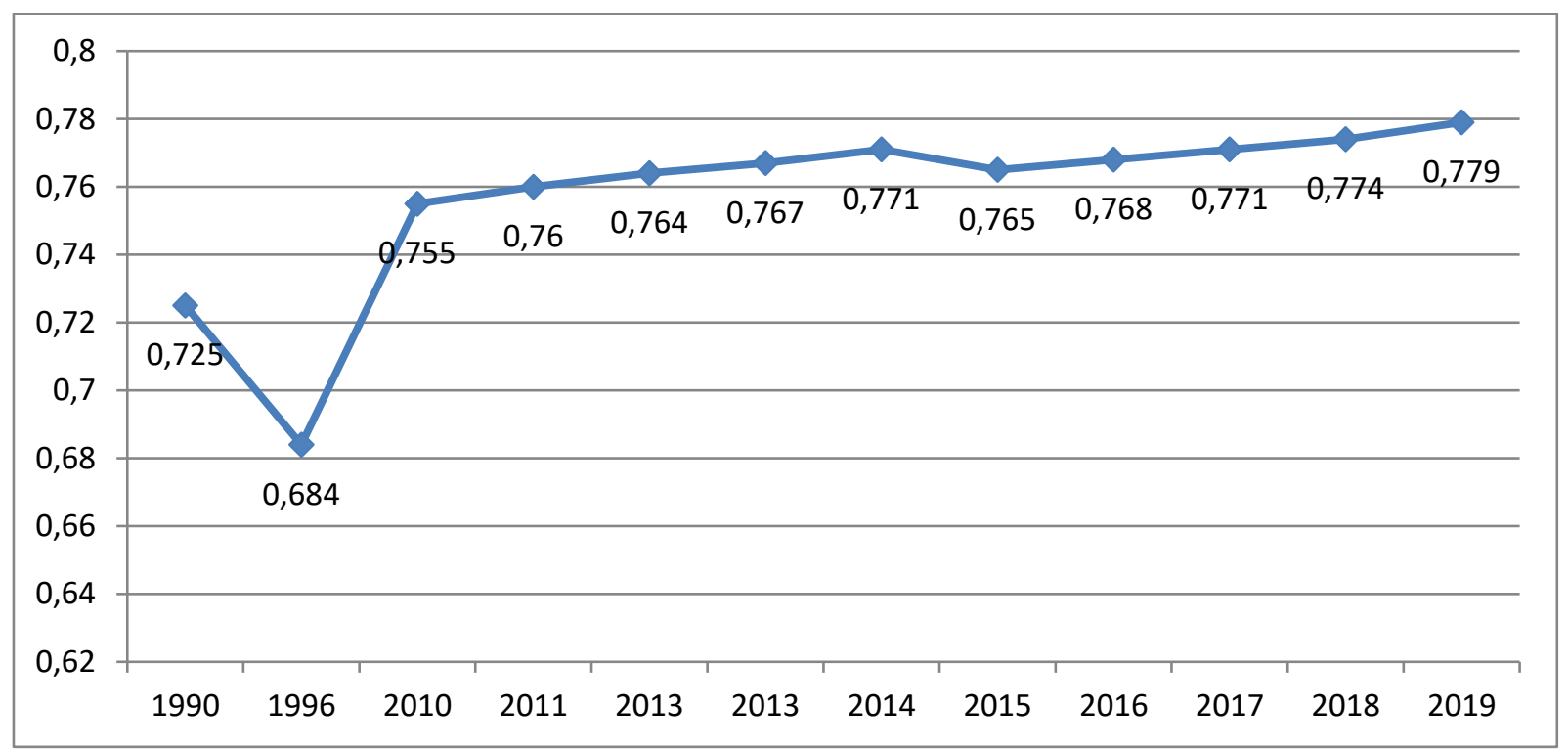

Рис. 1. Динаміка Індексу людського розвитку України за 1990-2019 роки

У 2020 році ПРООН представило показники HDI за 2019 рік, за якими країною, що характеризується найвищим рівнем людського розвитку було визначено Норвегію $(0,957)$. Також до десятки найкращих увійшли Ірландія $(0,955)$, Швейцарія $(0,955)$, Китай/Гонконг $(0,949)$, Ісландія $(0,949)$, Німеччина $(0,947)$, Швеція $(0,945)$, Австралія $(0,944)$, Нідерланди $(0,944)$, Данія $(0,94)$. У свою чергу, Україна $(0,779)$ посіла 74 сходинку серед 189 країн, яку наша країна поділяє з Гренадою, Мексикою, Сент-Кіттсом і Невісом. Слід зазначити, що це найкращий показник України за всі роки підготовки такого рейтингу (див. рис. 1). Найнижче значення спостерігаємо у 1996 році. Отже, у 2019 році маємо покращення у порівнянні з попереднім роком на 0,7\%, а у порівнянні з 1990 роком - на 7\%. Усі територіальні сусіди нашої країни у рейтингу знаходяться вище (Польща - 35 позиція $(0,880)$, Словаччина - 39 (0,860), Угорщина - 40 $(0,854)$, Румунія - 49 (0,828), Росія - 52 (0,824), Білорусь - $53(0,823))$, окрім Молдови - 90 позиція $(0,750)$ [220]. 


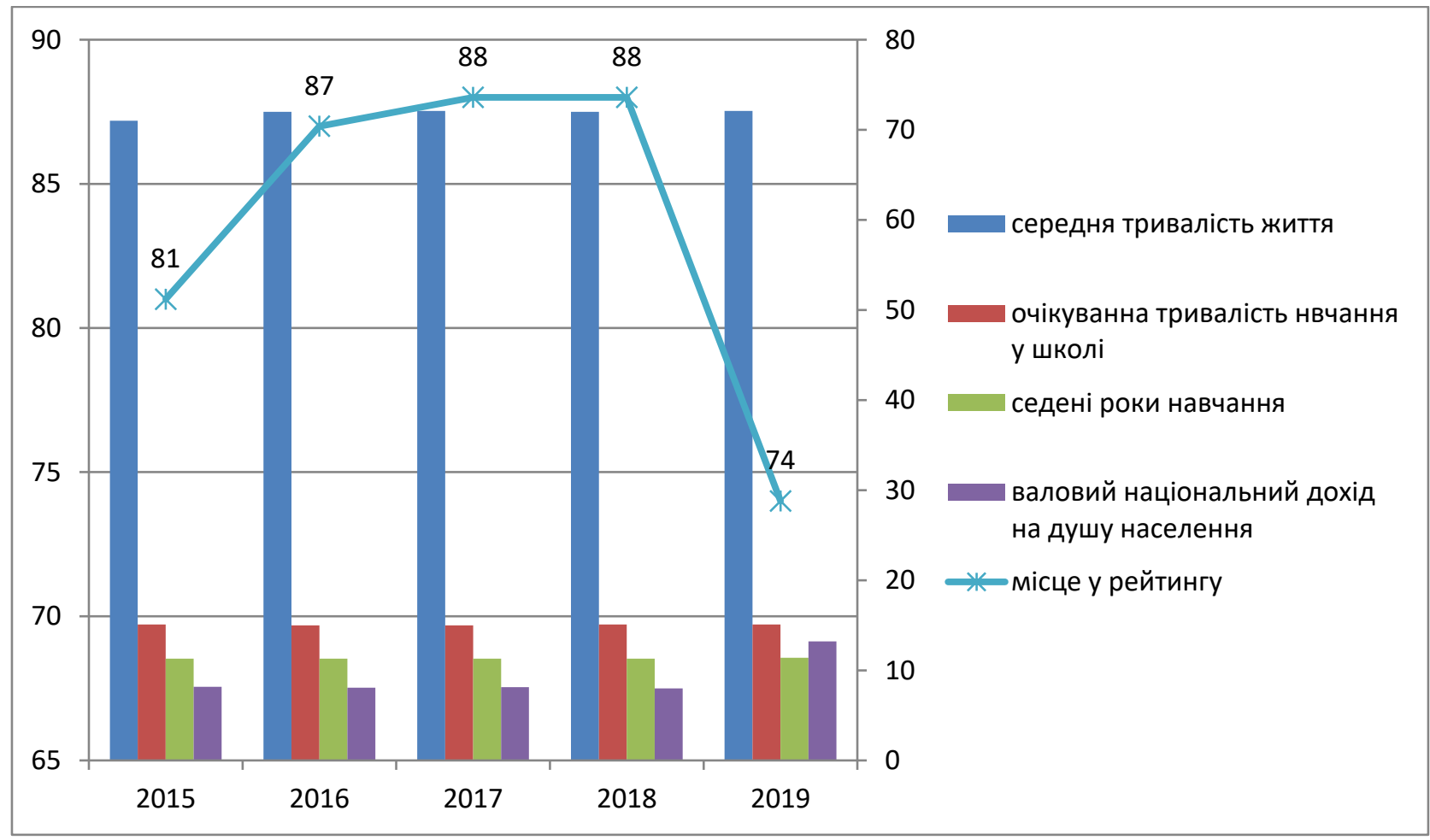

Рис. 2. Аналіз динаміки зміни складових Індексу людського розвитку України за 2015-2019 роки

Тобто Україна залишається одним з аутсайдерів серед європейських країн за розвитком людини, що є вкрай негативним для визначення подальшого шляху розвитку та досягнення стратегічних цілей у майбутньому. Адже талановита та креативна молодь вимушена шукати закордоном гідні умови життя та праці, що дозволить їм ефективно використовувати власний людський капітал, формування якого, з іншої сторони, відбувається в України. Тим самим наша країна може втрачати цінний людський ресурс, на формування якого спрямовує значні фінансові, часові та інші ресурси. Таким чином, у порівнянні з дорослим населенням сусідніх країн вітчизняна молодь має мізерні можливості стати продуктивним та кваліфікованим робітником 3 гідними умовами та оплатою праці. Аби покращити ситуацію необхідно збільшити кількість інвестицій в освіту, медицину, соціальний захист населення, прагнути до зупинення міграції населення в інші країни. А також прагнути до переймання досвіду високорозвинутих країн у питанні реформування зазначених систем. 
За індексом людського розвитку усі країни розподіляються на чотири групи: 1 - країни 3 дуже високим людським розвитком (у 2020 році мають показник ІЛР більший за 0,804); 2 - країни з високим людським розвитком (ІЛР у діапазоні від 0,703 до 0,796). Відповідно до представленої градації Україна віднесена до даної групи; 3 - країни з середнім розвитком людини (ІЛР від 0,554 до 0,697); 4 - країни $з$ низьким розвитком людини (ІЛР менший за 0,546).

Як видно з рис. 2 зростання 2019 року було здебільшого досягнуто за рахунок збільшення валового національного доходу на душу населення, що у порівнянні з 2018 року склало 65\%. Проте, у 2020-2021 роках не варто очікувати збільшення, оскільки пандемія коронавірусної інфекції привела до зменшення доходів населення через зниження загальної економічної активності та загострила проблеми економічного спаду в цілому.

Ще одним індексом, що опосередковано відображає стан розвитку людського капіталу є Глобальний індекс інновацій (Global Innovation Index), що по суті виступає середнім значенням двох субіндексів. Перший - субіндекс інноваційних витрат (Innovation Input), за яким здійснюється оцінка загальних елементів національної економіки, що позначаються на перебігу інноваційних процесів. До них належать такі складові:

1) інституції, за якими аналізується політичне середовище, регуляторне середовище та бізнес-середовище;

2) людський капітал i дослідження. В межах даного показника визначається стан розвитку освіти в цілому та вищої освіти зокрема, а також рівень проведення науково-дослідних та дослідно-конструкторських робіт;

3) інфраструктура, до складу якої зараховують загальну інфраструктуру, інформаційно-комунікаційні технології, екологічну стійкість;

4) рівень розвитку ринку, що визначається кредитною політикою, інвестиційною політикою, конкурентними відносинами, торгівельними операціями та масштабами ринку; 
5) рівень розвитку бізнесу або бізнес-досвід (висококваліфіковані робітники та частка зайнятості у наукоємних галузях, інноваційні зв'язки, рівень поглинання знань).

Другий - субіндекс інноваційних результатів (Innovation Output), який відображає рівень досягнутих результатів за такими елементами як: знання та результати наукового пошуку (рівень розробки нових знань, техніки, технології, темпи їх поширення та вплив на знання), а також креативність або результати творчої діяльності (аналізуються нематеріальні активи, частка новітніх (креативних) товарів та послуг, інтернет-творчість тощо).

У 2021 році до п'ятірки найкращих країн світу за даним рейтингом несподівано увійшла Південна Корея, відповідно ТОР 10 країн стала виглядати таким чином: Швейцарія, Швеція, США, Великобританія, Південна Корея, Нідерланди, Фінляндія, Сінгапур, Данія, Німеччина. Україна у цьому році втратила чотири сходинки й обіймає 49 позицію. Поряд з Україною у рейтингу 2020 року розташовані Греція (47 позиція), Румунія (48), Чорногорія (50), Філіппіни (51). Із територіально сусідніх країн найкраще положення займає Словаччина (37) [221].

Аналіз даних табл. 1 свідчить, що у 2021 році Україна втратила рейтингові показники, у першу чергу, за рахунок зменшення індексів, що відображають розвиток людського капіталу та креативності. Вважаємо, що суттєвий вплив на таке становище мала пандемія COVID-19. Проте, незважаючи на такі негативні зміни саме такі критерії, у порівнянні з іншими, зберігають сильні позиції. Й такі засади $\epsilon$ не випадковими, оскільки важливою складовою вітчизняної інноваційної конкурентоспроможності виступає людський капітал, знання та результати наукового пошуку. Їх ефективна реалізація визначається як головна конкурентна перевага національної економіки України. Саме тому важливу увагу сьогодні держава надає зростанню освітнього потенціалу, який $\epsilon$ невід’ємною складовою людського капіталу. Дійсно, сучасне суспільство зацікавлене у багатогранному та гармонійному розвитку особистості, індивідуальній свідомості та формуванню на цій основі висококваліфікованих та 
освічених фахівців. До того ж поширеною $є$ точка зору, що знання $є$ одним із головних чинників фінансової стійкості держави.

Таблицяя 1.

Динаміка зміни Глобального індексу інновацій України

\begin{tabular}{|l|l|l|l|l|l|l|l|}
\hline & 2015 & 2016 & 2017 & 2018 & 2019 & 2020 & 2021 \\
\hline Глобальний індекс інновацій & $\mathbf{6 4}$ & $\mathbf{5 6}$ & $\mathbf{5 0}$ & $\mathbf{4 3}$ & $\mathbf{4 7}$ & $\mathbf{4 5}$ & $\mathbf{4 9}$ \\
\hline Innovation Inриt & 84 & 76 & 77 & 75 & 82 & 71 & 76 \\
\hline Institutions & 98 & 101 & 101 & 107 & 96 & 93 & 91 \\
\hline Human capital \& research & 36 & 40 & 41 & 43 & 51 & 39 & 44 \\
\hline Infrastructure & 112 & 99 & 90 & 89 & 97 & 94 & 94 \\
\hline Market sophistication & 89 & 75 & 81 & 89 & 90 & 99 & 88 \\
\hline Business sophistication & 78 & 73 & 51 & 46 & 47 & 54 & 53 \\
\hline Innovation Output & 64 & 40 & 40 & 35 & 36 & 37 & 37 \\
\hline Knowledge \& technology outputs & 34 & 33 & 32 & 27 & 28 & 25 & 33 \\
\hline Creative outputs & 75 & 58 & 49 & 45 & 42 & 44 & 48 \\
\hline
\end{tabular}

Інноваційний індекс Європейського інноваційного табло покликаний аналізувати результати реалізації інноваційної політики на основі 27 індикаторів, розподілених на 10 блоків, більшість з яких наведено в таблиці 2. Такі засади дають можливість порівнювати інноваційну діяльність та участь людини в ній країн Свропейського співтовариства, країн-кандидатів на вступ у СС та деяких інших держав, а також визначати сильні та слабкі сторони національних інноваційних систем, що є допоміжним фактором у визначенні пріоритетних проблем, які необхідно вирішувати.

Серед сильних сторін у 2020 році визначено наявне інноваційне середовище, витрати на інновації та вплив на зайнятість. Крім того, Україна має доволі високі показники за такими індикаторами як зайнятість у наукомісткій діяльності, поширення широкосмугового інтернету (зв’язку), витрати на інновації, які не стосуються НДДКР, експорт наукомістких послуг. У той же час найслабші інноваційні виміри стосуються фінансів та підтримки інновацій, привабливості дослідницьких систем, інтелектуальної власності. До низько оцінюваних варто віднести такі показники як державні витрати на НДДКР, частка малих та середніх підприємств, що мають маркетингові або організаційні інновації, міжнародні видання науки i бізнесу Science-Metrix (Scopus). 
Поелементний аналіз Інноваційного індексу Європейського інноваційного табло дозволяє зробити висновок, що Україна має нереалізовані можливості, які стримують інноваційний розвиток, особливо це стосується захисту прав інтелектуальної власності та комерціалізації нововведень.

Таблиия 2.

\section{Динаміка зміни індексів Європейського інноваційного табло для України}

\begin{tabular}{|c|c|c|c|c|c|c|c|c|}
\hline & 2016 & 2017 & 2018 & 2019 & 2020 & 2021 & $\begin{array}{l}\text { Показники } \\
\text { лідера } \\
\text { табло } 2021 \\
\text { року } \\
\text { Швейцаріі }\end{array}$ & $\begin{array}{l}\text { Співвідношення } \\
\text { українських та } \\
\text { швейцарських } \\
\text { показників }\end{array}$ \\
\hline $\begin{array}{l}\text { Загальний } \\
\text { індекс } \\
\text { інновацій }\end{array}$ & 39,31 & 33,01 & 33,05 & 32,43 & 32,76 & 33,58 & 162,28 & 20,7 \\
\hline $\begin{array}{l}\text { Людські } \\
\text { ресурси }\end{array}$ & 45,18 & 46,04 & 41,74 & 41,86 & 34,36 & 41,86 & 222,61 & 18,8 \\
\hline $\begin{array}{l}\text { Привабливі } \\
\text { дослідницькі } \\
\text { системи } \\
\end{array}$ & 13,43 & 15,43 & 12,17 & 14,91 & 16,95 & 19,49 & 234,1 & 8,3 \\
\hline $\begin{array}{l}\text { Інноваційне } \\
\text { середовище }\end{array}$ & 106,06 & 106,06 & 106,06 & 106,06 & 99,66 & 99,66 & 211,43 & 47,14 \\
\hline $\begin{array}{ll}\text { Фінанси } & \text { i } \\
\text { підтримка } & \\
\text { інновацій }\end{array}$ & 14,48 & 16,46 & 21,32 & 21,52 & 27,58 & 41,26 & 94,40 & 43,7 \\
\hline $\begin{array}{ll}\text { Витрати } \\
\text { iнноваціï }\end{array}$ & 48,56 & 53,99 & 50,55 & 48,96 & 49,57 & 49,57 & 95,75 & 51,77 \\
\hline Зв язки & 4,17 & 4,9 & 6,97 & 9,0 & 11,40 & 13,68 & 216,05 & 6,3 \\
\hline $\begin{array}{l}\text { Інтелектуальна } \\
\text { власність }\end{array}$ & 6,29 & 8,33 & 8,67 & 8,35 & 8,22 & 8,51 & 153,61 & 54,52 \\
\hline $\begin{array}{ll}\text { Вплив } & \text { на } \\
\text { зайнятість } & \end{array}$ & \begin{tabular}{|l}
103,94 \\
\end{tabular} & 79,61 & 79,61 & 79,61 & 79,61 & 79,61 & 173,29 & 45,94 \\
\hline $\begin{array}{l}\text { Вплив } \\
\text { експорт }\end{array}$ & 40,52 & 37,81 & 36,25 & 38,18 & 38,18 & 38,18 & 105,39 & 36,23 \\
\hline
\end{tabular}

У 2021 році Україна посідає 38 сходинку з 38 представлених країн за Інноваційним індексом Європейського інноваційного табло [222]. До п’ятірки лідерів увійшли такі європейські країни як Швейцарія, Швеція, Фінляндія, Данія, Бельгія, що складають так звану групу «інноваційних лідерів». Усі країни, що представлені у табло, в залежності від значень узагальнюючого індексу, поділені на чотири групи, зокрема:

1) інноваційні лідери, сумарний індекс яких є вищим за середній по ЄС;

2) сильні новатори, інноваційні показники яких перевищують або близькі до середнього по ЄС (Австрія, Великобританія, Ісландія, Ірландія, Ізраїль, Естонія, Люксембург, Нідерланди, Німеччина, Норвегія, Франція); 
3) помірні новатори, які демонструють інноваційні показники нижчі за середні по ЄС (Греція, Іспанія, Італія, Кіпр, Литва, Мальта, Португалія, Словенія, Чехія);

4) скромні або повільні новатори, інноваційні показники яких $є$ приблизно на 50\% нижче за середні по ЄС (Болгарія, Боснія та Герцеговина, Латвія, Македонія, Польща, Румунія, Сербія, Словаччина, Туреччина, Угорщина, Україна, Хорватія, Чорногорія).

На жаль, Україна представляє останню групу й порівняння основних показників з лідером (див. табл. 2) дозволяє зробити невтішні висновки. Адже лише за двома статтями (витрати на інновації та інтелектуальна власність) маємо результати, які б дозволили увійти до групи більш вищого порядку. За трьома показниками (привабливі дослідницькі системи, зв’язкии та людські ресурси) наша країна є аутсайдером, на що необхідно звертати увагу державним органам. Результати аналізу представлення України у загальному індексі інновацій Європейського інноваційного табло дає підстави зробити висновок, що для досягнення економічного зростання не в повному обсязі використовуються наявні переваги такі як ємний ринок, високий рівень розвитку людського капіталу, наявність поглибленої та всебічної зони вільної торгівлі між Україною та $\mathrm{CC}$, сприятливе географічне положення.

Також варто визначити, що не випадково першим блоком в індексі інновацій Європейського інноваційного табло $є$ людські ресурси, який формується на основі таких показників як: нові випускники аспірантури/докторантури; частка населення 3 вищою освітою; частка населення, що навчається. Визнання людських ресурсів як базового блоку обумовлено тим, що без людини, іiї знань, вмінь, діяльності, креативності тощо інновації є неможливими. Проте, аналіз табл. 2 вказує на невтішні негативні тенденції, що передбачають поступове зменшення якості людського ресурсу в Україні. Так, за останні п’ять років таке скорочення становить майже 8\%. Кризовим в даному питанні став 2020 рік, але, у першу чергу, таке становище було обумовлено поширенням короновірусної інфекції. Невтішні висновки 
можна отримати в результаті порівняння якості розвитку людських ресурсів України з лідером рейтингу - Швейцарією, які є гіршими понад як у 5 разів. Отже, існуючі на вітчизняному просторі умови розвитку людських ресурсів не зможуть надати можливість нашій країні найближчим часом покращити становище.

Дослідження представлення України у міжнародних рейтингах, що прямо або опосередковано відображають рівень розвитку людського капіталу, свідчить про погіршення умов людського розвитку на вітчизняному просторі, особливо протягом останніх двох років. Така ситуація пов'язана 3 погіршенням економічної ситуації в країні, недостатньою результативність задекларованих реформ й відсутністю прозорої політики уряду, що суттєво стримує подальший розвиток людського капіталу, в результаті чого найближчим часом Україна не зможе покращити свої рейтингові позиції.

Таким чином, проведений аналіз дозволяє констатувати, що Україна має досить високу якість розвитку людського капіталу та високий рівень знань. Проте, низькі місце у міжнародних рейтингах, що відображають стан розвитку людського капіталу більшою мірою обумовлені неефективними методами управління людським капіталом. Крім того, відчутним є деякий спад протягом останніх двох років, що викликано загостренням пандемії COVID-19, яка має суттєвий вплив на людину та обмеження іï можливостей щодо подальшого розвитку. Саме тому вітчизняний уряд має знайти дієві урядові програми щодо відновлення розвитку людського капіталу, без якого досягнення сталого економічного зростання є неможливим. 